E3S Web of Conferences 1, 29009 (2013)

DOI: $10.1051 / \mathrm{e} 3$ sconf/20130129009

(C) Owned by the authors, published by EDP Sciences, 2013

\title{
Cadmium Induced Changes of Proline in Two Ecotypes of Thlaspi Caerulescens
}

\author{
$\underline{\text { V. Zemanová }}^{1}$, D. Pavlíková ${ }^{1}$ and J. Najmanová ${ }^{1}$ \\ ${ }^{1}$ Department of Agro-Environmental Chemistry and Plant Nutrition, Czech University of Life Sciences Prague, \\ Kamýcká 129, 16521 Prague 6-Suchdol, Czech Republic; zemanovav@af.czu.cz; pavlikova@af.czu.cz; \\ najmanova@af.czu.cz
}

\begin{abstract}
A Thlaspi caerulescens (J. \& C. PRESL) was used to study the effect of cadmium on the content of free amino acids and ability accumulation of $\mathrm{Cd}$ in ecotypes of this plant species. In pot experiment two ecotypes T. caerulescens were used: Ganges ecotype from France and Mežica ecotype from Slovenia. The plants were grown in soil (chernozem - Suchdol) spiked with NPK and three different concentration of Cd: 30 , 60 and $90 \mathrm{mg} / \mathrm{kg}$. The content of Cd was measured in the above-ground biomass and roots using ICP-OES. Accumulation of $\mathrm{Cd}$ was higher in the Mežica ecotype in contrast to the low Cd-accumulating the Ganges ecotype. Analyses of free amino acids contents were measured by GC-MS method. The content of free amino acids in above-ground biomass of the Mežica ecotype declined progressively with increasing concentrations of Cd. Opposite trend was observed in roots of this ecotype. The increase of free amino acids contents in above-ground biomass and roots of the Ganges ecotype were detected. The results of specific amino acids free proline showed increased content in plant biomass with increasing Cd contamination of soil. A statistically significant increase was observed between control plants $(0 \mathrm{mg} / \mathrm{kg} \mathrm{Cd})$ and variant $\mathrm{Cd} 3(90 \mathrm{mg} / \mathrm{kg} \mathrm{Cd})$ for both ecotypes. The statistically significant decrease of free proline was observed in the Mežica ecotype roots. Opposite trend was observed in roots of Ganges ecotype - increasing trend of free proline content. These results indicate a correlation between content of $\mathrm{Cd}$ and content of free proline in different parts of the plant. We can speculate that the mechanism of Cd hyperaccumulation and metabolism of free proline are not identical in ecotypes of this species.
\end{abstract}

Key words: Heavy metals, amino acids, contamination, hyperaccumulator plant, accumulation

\section{Introduction}

Cadmium (Cd) is a non-essential element that can be highly phytotoxic. Influences of cadmium on plant growth and the mechanism of its accumulation in plants are major aspects of the studies on the eco-environmental effects of cadmium (Chen et al., 2003).

$\mathrm{Cd}$ accumulation in plants causes DNA repair inhibition (Banerjee and Flores-Rozas, 2005), reduction in photosynthesis, water and nutrient uptake (Sanità di Toppi and Gabbrielli, 1999), and visible symptoms of injury such as chlorosis, growth inhibition, browning of root tips, and finally death (Hassan and Aarts, 2010). Some plants have developed the ability to survive in highly Cd-contaminated soils and to accumulate large amounts of $\mathrm{Cd}$ in their tissues. These plants are called as hyperaccumulators. Baker et al. (2000) defined hyperaccumulator plants as plants which accumulate up to $100 \mathrm{mg} \mathrm{Cd} \mathrm{kg}{ }^{-1}$ in shoots. However, to date, only a few plant species have been identified as Cd-hyperaccumulators: Thlaspi caerulescens (J. \& C. PRESL), Thlaspi goesingense (Halácsy), Thlaspi praecox (Wulfen), Arabidopsis halleri (O'KANE a AL SHEHBAZ), Sedum alfredii (Hance) and Rubia tinctorum (L.) (Lombi et al., 2000; Yang et al., 2004; Deng et al., 2007). Hyperaccumulation of heavy metals by higher plants is a complex phenomenon. It is likely to involve several steps, including metal transport across plasma membranes of root cells, xylem loading and translocation, detoxification, and sequestration of metals at the whole plant and cellular level (Lombi et al., 2002). It is assumed that most of the hyperaccumulated metals are bound to ligands such as organic acids, amino acids, peptides, and proteins (Sun et al., 2011).

T. caerulescens (J. \& C. PRESL) is the best known hyperaccumulator and is widespread in Western Europe 
on various metalliferous soil types, including mine wastes or smelter sites (Reeves et al., 2001). $T$. caerulescens, population in the Ganges region (South of France) has been proposed as the most promising population as a model hyperaccumulator (Peer et al., 2003). Moreover, this population was shown to hyperaccumulate $\mathrm{Cd}$ in its shoot, to a level probably unprecedented in living organisms, without apparent toxicity symptoms (Roosens et al. 2005). In $T$. caerulescens, $\mathrm{Cd}$ has been found in the apoplast and in the vacuole (Cosio et al., 2004). It has been demonstrated that the physiological mechanism of Cd tolerance is not based on an enhanced synthesis of phytochelatins (Schat et al., 2002). Upon exposure to $\mathrm{Cd}$ and other heavy metals, plants often synthesize a set of diverse metabolites that accumulate to concentrations in the millimolar range, particularly peptides, phytochelatins, amines and specific amino acids (Sharma and Dietz, 2006). One of specific amino acids, which heavy metals stress leads to accumulation is proline (Pro). Proline accumulation, accepted as an indicator of environmental stresses, is also considered to have important protective roles (Sharma et al., 1998). Although much is now known about proline metabolism, some aspects of its biological functions are still unclear (Szabaods and Savouré, 2010).

\section{Materials and Methods}

Pot experiment: The effect of $\mathrm{Cd}$ concentration on the levels of free amino acids was investigated in the pot experiment. For the pot experiment, we selected 2 ecotypes of Thlaspi caerulescens (J. \& C. PRESL): Ganges (France) and Mežica (Slovenia). The ecotypes were planted into plastic pots containing soil - $3 \mathrm{~kg}$ of Chernozem (Table 1). Soil was thoroughly mixed with $0.3 \mathrm{~g} \mathrm{~N}, 0.10 \mathrm{~g} \mathrm{P}$, and $0.24 \mathrm{~g} \mathrm{~K}$ applied in the form of ammonium nitrate and potassium hydrogen phosphate for control treatment and with the same amount of nutrients plus $\mathrm{Cd}$ in form $\mathrm{Cd}\left(\mathrm{NO}_{3}\right)_{2} \cdot 4 \mathrm{H}_{2} \mathrm{O}$ in concentrations: 0 (control), $30(\mathrm{Cd} 1), 60(\mathrm{Cd} 2)$ and $90(\mathrm{Cd} 3) \mathrm{mg} \cdot \mathrm{kg}^{-1}$, for treated variants. The plants were cultivated under natural light and temperature conditions at the experimental hall. Plants were harvested 30, 60, 90 and 120 days after treatment. Samples were kept frozen in liquid $\mathrm{N}$ for transport and then at $-30^{\circ} \mathrm{C}$ until extraction procedure.

Determination of $C d$ : Plant samples were decomposed using the dry anhing procedure as follows: an aliquot $(\sim 0.5 \mathrm{~g})$ of the dried and powdered biomass was weighed into silica glass test-beaker and burned at $160,220,280,350,450{ }^{\circ} \mathrm{C}$ (for $1 \mathrm{~h}$ ) and $500{ }^{\circ} \mathrm{C}$ for $15 \mathrm{~h}$. The ash was dissolved in $20 \mathrm{~mL}$ of $1.5 \% \mathrm{HNO}_{3}(\mathrm{v} / \mathrm{v})$ (electronic grade purity, Analytika Ltd., Czech Republic) (Miholová et al., 1993). The concentrations of Cd were determined by ICP-OES (VarianVistaPro, Varian, Australia).

Determination of free AA: Samples were homogenized in liquid $\mathrm{N}$ and free AA compounds were extracted from $0.5 \mathrm{~g}$ (fresh weight) frozen plant tissue
Table 1. Basic characteristics and total element contents in experimental soil.

\begin{tabular}{l|c}
\hline Soil type & Chernozem \\
\hline $\mathrm{pH}$ & $7.2 \pm 0.1$ \\
$\mathrm{C}_{\text {org }}(\%)$ & $1.83 \pm 0.01$ \\
$\mathrm{CEC}\left(\mathrm{mmol}_{(+)} / \mathrm{kg}\right)$ & $258 \pm 0.1$ \\
$\mathrm{Cd}(\mathrm{mg} / \mathrm{kg})$ & $0.42 \pm 0.05$ \\
\hline
\end{tabular}

with $10 \mathrm{ml}$ of methanol and $\mathrm{H}_{2} \mathrm{O}$ in ratio $7: 3(\mathrm{v} / \mathrm{v})$ for $24 \mathrm{~h}$.

Homogenate was centrifuged $20 \mathrm{~min}$ at $9000 \mathrm{~g}$. In supernatant were determined the free AA using EZ:faast amino acid analysis procedure (Phenomenex, USA). Samples were analyzed for free AA content by GC/MS using HewlettPackard 6890N/5975 MSD (Agilent Technologies, USA; Pavlík et al. 2010).

Statistical analysis: All statistical analyses were performed using hierarchic analyses of variance (ANOVA) with inteactions at a 95\% (P<0.05) significance level with a subsequent Tukey's HSD test. All analyses were performed by using the Statistica 9.1 software (StatSoft, USA).

\section{Results and Discussion}

The results indicated different accumulation of $\mathrm{Cd}$ between ecotypes $T$. caerulescens (Figure 1 and 2). The Mežica ecotype is more accumulates to $\mathrm{Cd}$ than the Ganges ecotype, but the Ganges ecotype is more tolerant to $\mathrm{Cd}$. This is consistent with the results of Lombi et al. (2000), where different accumulation of $\mathrm{Cd}$ between ecotype Ganges and ecotype Prayon (Belgium) was observed. Figure 1 shows greater accumulation of $\mathrm{Cd}$ in roots the Ganges ecotype. Opposite phenomenon was showed of the Mežica ecotype. This result is in contrast with claim Benavides et al. (2005) which indicate that most $\mathrm{Cd}$ is stored in the roots.

The content of total free AA showed decrease trend in above-ground biomass ecotype Ganges and opposite trend was found in the roots. The ecotype Mežica did not show significant trend in content of total free AA. The presence of $\mathrm{Cd}$ in soil induced the accumulation of free Pro in above-ground biomass both ecotypes of $T$. caerulescens. According to Alia and Saradhe (1991) Cd proved to be strong inducer of free Pro in plant species.

In the above-ground biomass of both ecotypes increase of free Pro (Figure 3 and 4). Accumulation of free proline in response to trace elements exposure seems widespread among plants (Costa and Morel 1994). Zengin and Munzuroglu (2006) reported similar results of increasing Pro content by $\mathrm{Cd}^{2+}$ in sunflower.

Content of free Pro in roots ecotype Ganges increase with increasing concentration of $\mathrm{Cd}$ in soil (Figure 3). Opposite trend decresed content of free Pro was found in roots ecotype Mežica (Figure 4). 


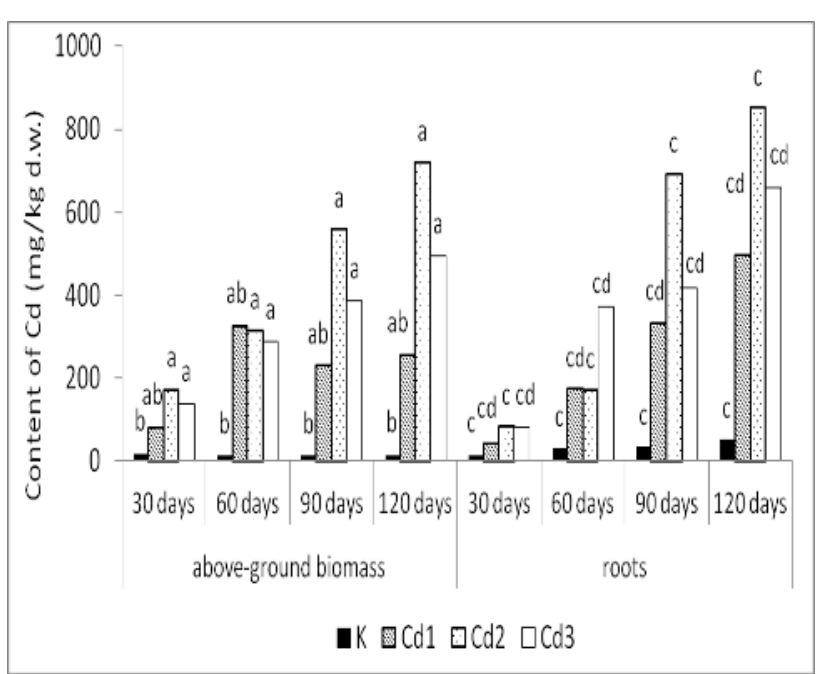

Fig. 1. Total content of $\mathrm{Cd}$ in above-ground and roots ecotypes Ganges $(n=2 ; n=1)$.

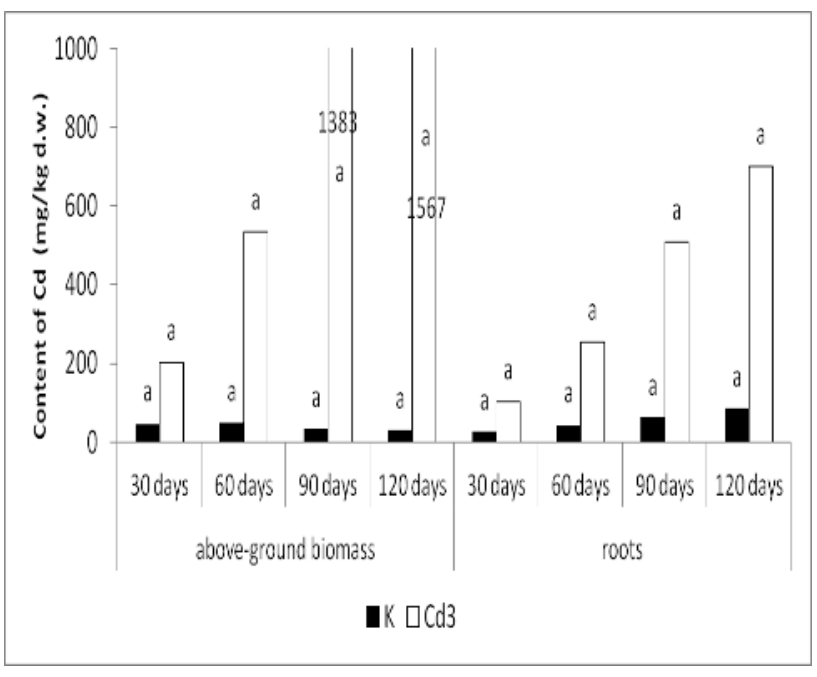

Fig. 2. Total content of $\mathrm{Cd}$ in above-ground and roots ecotypes Mežica $(n=2 ; n=1)$.

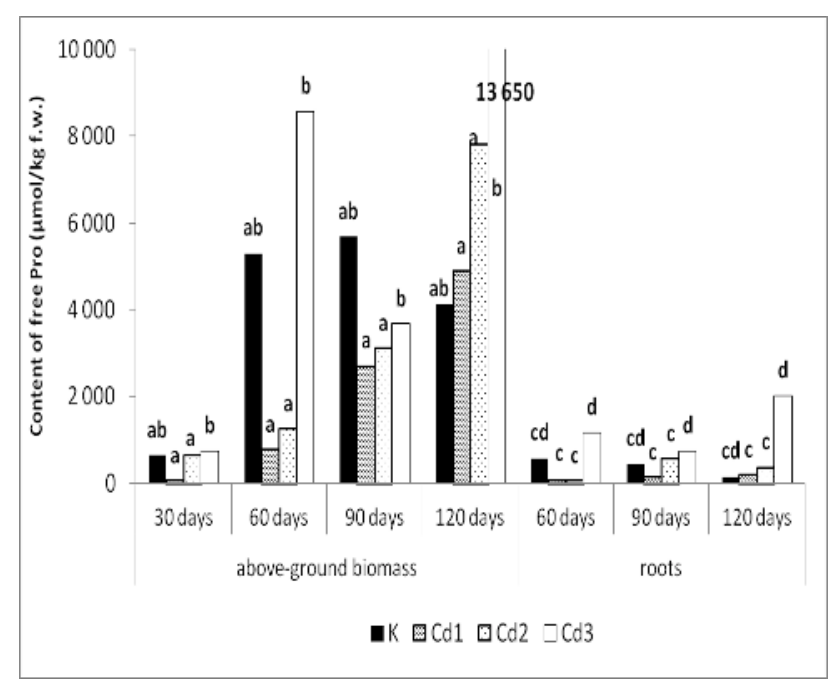

* in an 30 days is not data due to lack of biomass for analysis AA in roots

Fig. 3. Content of free Pro in above-ground and roots ecotype Ganges depending on the dose $\mathrm{Cd}$ in soil $(\mathrm{n}=3)$.

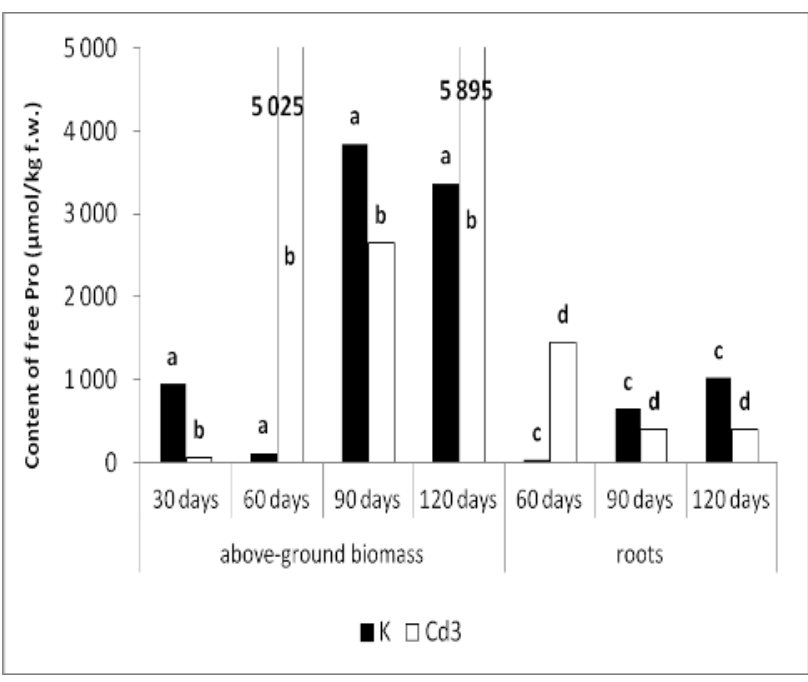

* in a 30 days is not data due to lack of biomass for analysis AA in roots

Fig. 4. Content of free Pro in above-ground and roots ecotype Mežica depending on the dose $\mathrm{Cd}$ in soil $(\mathrm{n}=3)$.

\section{Conclusion}

The results of pot experiment focused on $\mathrm{Cd}$ hyperaccumulator Thlaspi caerulescens show different behavior of two ecotypes of this plant species. Accumulation of $\mathrm{Cd}$ is higher in the Mežica ecotype than the Ganges ecotype. However tolerance to $\mathrm{Cd}$ is better in the Ganges ecotype. The differences in metabolism of free amino acids, especially free proline, were determined. The results indicate a correlation between content of free proline and content of $\mathrm{Cd}$ in plant. It was confirmed that the two ecotypes of this plant species are differed in metabolism.

\section{Acknowledgements}

The authors thank the financial supports providing from S grant of MSMT CR and from CIGA, Project No. 20122014 of CULS.

\section{References}

Alia, Saradhi PP. Proline accumulation under heavy metal stress. J Plant Physiol 1991; 138: 504-508.

Baker AJM, McGrath SP, Reeves RD, Smith JAC. Metal hyperaccumulator plants: a review of the ecology and physiology of a biochemical resource for phytoremediation of metal-polluted soils in: Phytoremediation of contaminated soil and water, ed. Terry N. and G. Bañuelos, Boca Raton, FL: Lewis Publishers 2000: 85-107.

Banerjee S, Flores-Rozas H. Cadmium inhibits mismatch repair by blocking the ATPase activity of the MSH2-MSH6 complex. Nucleic Acids Res 2005; 33: $1410-1419$.

Benavides MP, Gallego SM, Tomaro ML. Cadmium 
toxicity in plants. Braz J Plant Physiol 2005; 17 (1): 21-34.

Chen YX, He YF, Luo YM, Yu YL, Lin Q, Wong MH. Physiological mechanism of plant roots exposed to cadmium. Chemosphere 2003; 50: 789-793.

Cosio C, Martinoia E, Keller C. Hyperaccumulation of cadmium and zinc in Thlaspi caerulescens and Arabidopsis halleri at the leaf cellular level. Plant Physiol 2004; 134: 716-725.

Costa G., Morel JL. Water relations, gas exchange and amino acid content in Cd-treated lettuce. Plant Physiol Bioch 1994; 32: 561-570.

Deng DM, Shu WS, Zhang J, Zou HL, Ye ZH, Wong $\mathrm{MH}$, Lin Z. Zinc and cadmium accumulation and tolerance in populations of Sedum alfredii. Environ Pollut 2007; 147: 381-386.

Hassan Z, Aarts MGM. Opportunities and feasibilities for biotechnological improvement of $\mathrm{Zn}, \mathrm{Cd}$ or $\mathrm{Ni}$ tolerance and accumulation in plants. Environ Exp Bot 2011; 72: 53-63.

Lombi E, Zhao FJ, Dunham SJ, McGrath SP. Cadmium accumulation in populations of Thlaspi caerulescens and Thlaspi goesingense. New Phytol 2000; 145: 11-20.

Lombi E., Tearall KL, Howarth JR, Zhao FJ, Hawkesford MJ, McGrath SP. Influence of iron status on cadmium and zinc uptake by different ecotypes of the hyperaccumulator Thlaspi caerulescens. Plant Physiol 2002; 128: 1359-1367.

Miholová D, Mader P, Száková J, Slámová A, Svato Z. 1993. Czechoslovak biological certified reference materials and their use in the analytical quality assurance systemin a trace element laboratory. Fresen J Anal Chem 1993; 51: 256-260.

Pavlík M, Pavlíková D, Balík J, Neuberg M. The contents of amino acids and sterols in maize plants growing under different nitrogen conditions. Plant Soil Environ 2010; 56: 125-132.

Peer WA, Mamoudian M, Lahner B, Reeves RD, Murphy AS, Salt DE. Identifying model metal hyperaccumulating plants: germplasm analysis of 20 Brassicaceae accessions from a wide geographical area. New Phytol 2003; 159: 421-430.

Reeves RD, Schwartz C, Morel JL, Edmondson J. Distribution and metal-accumulating behavior of Thlaspi caerulescens and associated metallophytes in France. Int J Phytoremediat 2001; 3: 145-172.

Roosens NH, Leplae R, Bernard C, Verbruggen N. Variations in plant metallothioneins: the heavy metal hyperaccumulator Thlaspi caerulescens as a study case. Planta 2005; 222: 716-729.

Sanità di Toppi L, Gabbrielli R. Response to cadmium in higher plants. Environ Exp Bot 1999; 41: 105-130.

Schat H, Llugany M, Vooijs R, Hartley-Whitaker J, Bleeker PM. The role of phytochelatins in constitutive and adaptive heavy metal tolerances in hyperaccumulator and nonhyperaccumulator metallophytes. J Exp Bot 2002; 53: 2381-2392.

Sharma SS, Schat H, Vooijs R. In vitro alleviation of heavy metal-induced enzyme inhibition by proline. Phytochemistry 1998; 49: 1531-1535.

Sharma SS, Dietz KJ. The significance of amino acids and amino acid-derived molecules in plant responses and adaptation to heavy metal stress. J Exp Bot 2006; 57(4): 711-726.

Sun R, Zhou Q, Wei S. Cadmium Accumulation in Relation to Organic Acids and Nonprotein Thiols in Leaves of the Recently Found $\mathrm{Cd}$ Hyperaccumulator Rorippa globosa and the Cd-accumulating Plant Rorippa islandica. J Plant Growth Regul 2011; 30: 83-91.

Szabados L, Savouré A. Proline: a multifunctional amino acid. Trends Plant Sci 2010; 15 (2): 89-97.

Yang XE, Long XX, Ye HB, He ZL, Calvert DV, Stoffella PJ. Cadmium tolerance and hyperaccumulation in a new Zn hyperaccumulating plant species (Sedum alfredii Hance). Plant Soil 2004; 259: 181-189.

Zengin FK, Munzuroglu O. Effect of some heavy metals on content of chlorophyll, proline and some antioxidant chemicals in bean (Phaseolus vulgarit L.) seedlings. Acta Biol Cracov Bot 2005; 47 (2): 157-164. 